\author{
Halina Wąsik \\ Uniwersytet Pedagogiczny \\ im. Komisji Edukacji Narodowej w Krakowie \\ Gimnazjum w Liszkach
}

\title{
Nauczanie przedsiębiorczości w kontekście integracji europejskiej
}

\section{Formowanie podejścia zaangażowania i inicjatywy w społeczeństwach XXI wieku}

Co takiego umie Hans, a czego nie umie Janek? - to parafraza tytułu raportu pt. „Co takiego umie Iwan, a czego nie umie John?". Sprawozdanie to zostało opublikowane po locie Jurija Gagarina w kosmos w Stanach Zjednoczonych i wskazywało na różnice w nauczaniu w szkołach oraz sterowaniu gospodarkami w USA i ZSRR. Amerykanie przestraszyli się tego, że Rosjanie wysłali w kosmos człowieka wcześniej niż oni. Poszukiwali przyczyn takiego stanu rzeczy, między innymi w systemach szkolnictwa, sposobach nauczania, a także w różnicach prowadzenia polityk gospodarczych i edukacyjnych. Po badaniach zaczęli zastanawiać się nad programem naprawczym. Podobną inicjatywę stworzenia programów mających na celu podniesienie poziomu konkurencyjności gospodarki podjęto w Europie. Zauważono, że edukacja w dziedzinie ekonomii w krajach europejskich jest opóźniona w stosunku do USA. Następstwem było opracowanie szeregu materiałów mających poprawić stan przedsiębiorczości na Starym Kontynencie. W dokumencie opublikowanym przez Komisję Europejską zatytułowanym „Pomoc w budowaniu przedsiębiorczej kultury” zaprezentowano sposoby tworzenia i wspierania poprzez edukację odpowiednich kompetencji przedsiębiorczych. W akcie tym wymieniono następujące aspekty nauczania przedsiębiorczości:

- kształtowanie przedsiębiorczości na poziomie szkół podstawowych,

- kształcenie nauczycieli przedsiębiorczości w zakresie przedsiębiorczego myślenia i działania,

- współpracę szkół, uniwersytetów i przedsiębiorstw w celu wspierania zawodowej niezależności,

- intensyfikacja nauczania przedsiębiorczości, również w uczelniach nieekonomicznych.

\section{Aspekty wychowywania w duchu przedsiębiorczości na różnych poziomach nauczania} Od 2004 roku w Polsce i w Niemczech dobrze rozpracowano aspekt kształcenia nauczycieli przedsiębiorczości dla szkół średnich. Wyedukowano świetną kadrę dydaktyczną, która naucza w liceach. Polska jest chwalona przez Komisję Europejską za wprowadzenie przedsiębiorczości do szkół średnich. Jeżeli chodzi o polskie gimnazja, to elementów przedsiębiorczości uczą przeważnie nauczyciele wiedzy o społeczeństwie i historii. Z tego względu warto jest wprowadzać elementy przedsiębiorczości do programów studiów nieekonomicznych, a do podręczników języka polskiego, historii i innych przedmiotów - przykłady nawiązujące do przedsiębiorczości. Jeżeli chodzi o współpracę uniwersytetów i przedsiębiorstw w celu wspomagania zawodowej niezależności młodych ludzi, to są organizowane wspólne targi, praktyki oraz specjalne Biura Promocji, które wspierają działania na rzecz studentów. Są one podobne w Niemczech i w Polsce, lecz w Niemczech jest więcej konkursów dla studentów 
sprawdzających ich umiejętności praktyczne. Schodząc na coraz niższe stopnie szkolnictwa, zauważamy coraz większe różnice w systemach i w nauczaniu. W kontaktach pomiędzy szkołami średnimi i przedsiębiorstwami lepiej wypadają Niemcy. Wynika to z długiej tradycji współpracy niemieckiego szkolnictwa zawodowego i systemu gospodarczego. Niemieccy uczniowie spędzają mało czasu w szkole zawodowej. Pracują i uczą się u przedsiębiorcy lub rzemieślnika. Mają identyczne obowiązki jak każdy zatrudniony w danej firmie pracownik, a dodatkowo piszą raporty z czynności i działań, które wykonywali w ciągu całego dnia pracy. Wykonując czynności zawodowe, przejmują dobre wzorce przedsiębiorczości. Dobra postawa wymaga wysiłku i pracy nad sobą.

W 2000 roku opublikowano główny cel Strategii lizbońskiej: „Gospodarka europejska powinna stać się najbardziej konkurencyjną i dynamiczną gospodarką w świecie, gospodarką opartą na wiedzy". Działania i fundusze dotyczące kształcenia przedsiębiorczych Europejczyków, a także modyfikacje podstaw programowych do nauczania przedsiębiorczości, były i są następstwem tego dokumentu. W 2002 roku na posiedzeniu Rady Europejskiej uchwalono program prac dotyczących przyszłych celów systemów edukacji pod tytułem: Edukacja w Europie: różne systemy kształcenia i szkolenia - wspólne cele do roku 2010. W punkcie trzecim tego opracowania znajduje się temat otwarcia systemów edukacji na środowisko i świat „W związku z koniecznością lepszego dostosowania edukacji do potrzeb pracy zawodowej i wymagań społeczeństwa”. Postanowiono w nim też m.in. zwiększać powiązania pomiędzy światem pracy, działalnością badawczą i społeczeństwem oraz rozwijać przedsiębiorczość.

Zdania o nieodzowności przedsiębiorczości w codziennym życiu i o konsekwencjach złych decyzji ekonomicznych człowieka są truizmem, jednak świadomość społeczna powyższych prawd jest ciągle niedostateczna. Coraz większe znaczenie ma kształtowanie ludzi pełnych inwencji, aktywnych, dobrze rozumiejących gospodarkę i prawo. Istotne jest skuteczne wychowanie aktywnej osoby już na poziomie przedszkolnym i nauczania początkowego. Jest to zadanie dla rodziców i nauczycieli bardzo trudne, ponieważ pokolenie z okresu przed transformacją ustrojową w Polsce było przyzwyczajone do bierności i posłuszeństwa. Były to cechy, które pomagały przetrwać w czasach socjalistycznych. Zmiana postaw zachodzi więc powoli. Zmiana ta lub cały szereg zmian osobowościowych i postaw w polskim społeczeństwie jest jednak warunkiem koniecznym do ewaluacji gospodarczej i politycznej. Kształtowanie przedsiębiorczości przygotowuje do różnych sytuacji życiowych, wyposaża w wielostronne umiejętności dające narzędzia do rozwiązywania problemów. Ogromny wpływ na formowanie przedsiębiorczego myślenia u dzieci już od przedszkola ma przygotowanie nauczycieli do wprowadzania na zajęcia odpowiednich gier edukacyjnych i zbaw modelujących postawę przedsiębiorczą. Edukacja przez rozrywkę powoduje bowiem, że praca staje się przyjemnością. Łatwiej jest zaszczepić odpowiednie cechy w dziecku niż w osobie dorosłej. Rodzice i nauczyciele muszą potrafić transplantować przedsiębiorczość społeczeństwu. „Większość nauczycieli traci czas na zadawanie pytań, które mają ujawnić to, czego uczeń nie umie, podczas gdy nauczyciel z prawdziwego zdarzenia stara się za pomocą pytań ujawnić to, co uczeń umie lub czego jest zdolny się nauczyć". Przytoczone słowa Einsteina w pełni ukazują, jak nauczyciel może wzmacniać lub zabijać aktywność ucznia.

W Niemczech po ogłoszeniu dokumentów Komisji Europejskiej utworzono forum, na którym wypowiadali się przedstawiciele ministerstw, nauczyciele przedsiębiorcy, przedstawiciele izby gospodarczej a także bankowcy. W czasopismach ukazało się bardzo dużo artykułów o konieczności nauczania „ekonomii” poprzez gry i zabawy w szkołach i przedszkolach. W naszym kraju inicjatywa zwiększania postaw przedsiębiorczych, a także szkoleń dla nauczycieli została podjęta między innymi przez Narodowy Bank Polski, ośrodki doskonalenia 
nauczycieli i uczelnie wyższe. Zorganizowano wiele bardzo cennych inicjatyw. Na poziomie szkolnictwa wyższego i doskonalenia nauczycieli zrobiono bardzo dużo. Teraz powstaje pytanie, co możemy zrobić, aby kształtować postawę przedsiębiorczości u dzieci. W nauczaniu przedsiębiorczości w Niemczech kładzie się nacisk na to, aby dzieci wyćwiczyły przedsiębiorcze myślenie i działanie.

Wychowanie w duchu zaradności to zadanie dla nauczycieli, rodziców oraz całej społeczności szkolnej i lokalnej. Pedagogika przedsiębiorczości polega na budzeniu kreatywnego myślenia i działania, twórczego rozwiązywania problemów, sprawnego porozumiewania się, aktywnego poszukiwania informacji, sztuki prezentacji czy pracy w grupie. Jak mówi M. Sielatycki: „Ucząc fizyki można uczyć przedsiębiorczości; są tacy, którzy potrafią to z powodzeniem robić, innych można takiego myślenia i działania uczyć poprzez doskonalenie". Wynika z tego, że nauczyciele przedmiotów nieekonomicznych powinni nawiązywać do przedsiębiorczości tam, gdzie to tylko jest możliwe.

Kształcenie w naszym kraju ciągle jeszcze zawiera dużo teorii i nauczania poprzez teorię. W Niemczech udziela się lekcji poprzez praktyczne ćwiczenia, dzięki którym uczeń dochodzi do teorii i formułuje definicje. Jest to jeden z przykładów znajdowania drogi do rozwijania postaw przedsiębiorczych i rozpoznawania potencjału młodego człowieka. Założeniem jednego z projektów w austriackiej szkole podstawowej jest np. hodowla pszczół i produkcja miodu w przyszkolnej pasiece przez dzieci. Jedna z uczennic jest ekspertką w dziedzinie pszczelarstwa i liderką grupy. Miód jest sprzedawany dla zysku, firma nazywa się „Młodzi Pszczelarze Spółka Akcyjna". Jednakże taki model rozwijania przedsiębiorczości w szkole podstawowej u dzieci ma swoich przeciwników wśród austriackich pedagogów. Nadmierny nacisk na rozwijanie kompetencji przedsiębiorczych, tj. aktywności, kreatywności, urzeczywistniania pomysłów i racjonalnego biznesowego myślenia może wpłynąć upośledzająco na nawiązywanie osobistych relacji albo empatię. Mogą pojawić się problemy interpersonalne i zaburzenia emocjonalne.

W szkole japońskiej dzieci są uczone współdziałania i pracy w zespole w kontekście biznesu i zatrudnienia w korporacjach. Mąż spędza większość czasu w miejscu pracy zawodowej. Firma egzystuje ciaggle w umyśle i sercu pracowników. Żona wykonuje swoje obowiązki w domu. Może się zorientować, że mąż jeszcze żyje dzięki temu, że na konto wpływają pieniądze. Gdy głowa rodziny przechodzi na emeryturę, bardzo często dochodzi do rozwodu. Małżonkom trudno jest bowiem dopasować się do siebie. Biznesowe myślenie może utrudniać rozwiązywanie problemów interpersonalnych i nawiązywanie osobistych relacji. Z drugiej strony świat żyje przecież biznesem i uświadamianie tego dzieciom wydaje się konieczne. Dlatego szkoła i gospodarka powinny być partnerami. Ważne jest wczesne odkrywanie talentów oraz kształtowanie u dzieci ekonomicznego spojrzenia na świat poprzez wprowadzenie odpowiednich gier i zabaw.

W Niemczech nauczanie przedsiębiorczości połączone jest z edukacją prawną. Wydaje się to słusznym rozwiązaniem, mającym praktyczne skutki np. w polsko-niemieckich stosunkach gospodarczych. Niemieccy kontrahenci są lepiej przygotowani do działalności gospodarczej aniżeli polscy. Również niemieckie prawo jest bardziej przyjazne dla postaw przedsiębiorczych. Niemieccy przedsiębiorcy, którzy chcą założyć oddziały swoich firm w Polsce, otrzymują dużą pomoc. W prasie można znaleźć ogłoszenia na ten temat. A czy znajdziemy ogłoszenia na temat wspomagania Polaków podczas zakładania firmy w Niemczech? Niestety brakuje tego typu konsultacji. Polscy przedsiębiorcy mają duże problemy z wyegzekwowaniem należności za towary wyeksportowane do niemieckich kontrahentów. Czy podobne problemy z uzyskaniem należności za towar wyeksportowany do Polski ma niemiecki przedsiębiorca? 
Wpływ na niekorzystną sytuację polskich przedsiębiorców ma nie tylko stan ich umiejętności i wiedzy o przedsiębiorczości, ale także stan prawny w Polsce. Zmieniający się świat wymaga nowej przedsiębiorczości.

Badania postaw przedsiębiorczych w Polsce wykazały, że znaczny odsetek młodych ludzi jest chętny do zakładania własnej firmy, jednak zapał ten szybko mija wskutek zetknięcia się młodego człowieka z zawiłymi przepisami i zasadami zakładania oraz prowadzenia własnej działalności gospodarczej. Problemy dotyczą także systemu rozliczeń z fiskusem i ZUS-em. Jeden z właścicieli polskiej firmy informatycznej działającej w Wielkiej Brytanii wypowiedział się podczas panelu dotyczącego Regionalnego Systemu Innowacji Województwa Małopolskiego na temat przyjaznego systemu brytyjskiego i nieprzyjaznego polskiego. Wynikiem takiej sytuacji były bezskuteczne próby wejścia ze sprawdzonymi na Wyspach Brytyjskich projektami na rynek polski. Dobry system pozwolił temu przedsiębiorcy na działanie na rynku brytyjskim. Zły system w Polsce uniemożliwia natomiast wprowadzanie dobrych projektów na rynek naszego kraju.

Od września 2009 weszła nowa podstawa programowa nauczania przedsiębiorczości w ramach zajęć z WOS w gimnazjum. W celach kształcenia nowej podstawy programowej na ostatnim, szóstym miejscu zamieszczono zapis: „Rozumienie zasad gospodarki rynkowej. Uczeń rozumie procesy gospodarcze oraz zasady racjonalnego gospodarowania w życiu codziennym; analizuje możliwości dalszej nauki i kariery zawodowej”. W dokumencie opublikowanym w 2000 roku z forum w Sophia-Antipolis (instytucja powołana do stworzenia i rozwijania przedsięwzięć skupionych na zaawansowanych technologiach) pt. Wyksztatcenie dla przedsiębiorczości na poziomie szkół podstawowych i średnich napisano, że celem kształcenia dla przedsiębiorczości jest przygotowanie ucznia do rozwiązywania problemów, planowania, podejmowania decyzji, komunikacji i przejmowania odpowiedzialności. Chodzi tu o rozwijanie typowych kompetencji kierowniczych - celem jest to, aby uczeń potrafił rozwiązywać problemy, planować, podejmować decyzje, komunikować się i przejmować odpowiedzialność. W dalszej części zaznaczono, że uczeń powinien umieć współpracować, tworzyć sieć kontaktów i przejmować zadania. Te aspekty odnoszą się do umiejętności społecznych. W trakcie nauki w szkole uczniowie nabywają pewność siebie, wiarę w odnoszenie sukcesów, zdolność samodzielnego, krytycznego myślenia, a w szczególności gotowość i zdolność do rozwoju autonomicznego uczenia się. Oznacza to, że na lekcjach z przedsiębiorczości uczniowie powinni nauczyć się, jak się uczyć. Jest to poziom kompetencji osobistych. Uczeń powinien być aktywny i kreatywny w urzeczywistnianiu swoich pomysłów i projektów. Powinien także umieć ocenić związane z tym ryzyko. Są to typowo przedsiębiorcze kompetencje.

Programy nauczania przedsiębiorczości wymagają stałej modyfikacji. W treściach nauczania podstawy programowej wiedzy o społeczeństwie w gimnazjum znajduje się punkt „Praca i przedsiębiorczość”. W ramach tego punktu uczeń ma wyjaśniać na przykładach z życia własnej rodziny, miejscowości i całego kraju, w jaki sposób praca i przedsiębiorczość pomagają w zaspokajaniu potrzeb ekonomicznych oraz przedstawić cechy i umiejętności człowieka przedsiębiorczego, a także brać udział w przedsięwzięciach społecznych pozwalających mu się rozwinąć. Uczeń ma też stosować w praktyce podstawowe zasady organizacji pracy (ustalać cele, planować, dokonywać podziału pracy, sporządzać harmonogram, oceniać efekty podejmowanych działań). Na etapie gimnazjum $20 \%$ treści ma być realizowane w formie projektu. Jest to postęp w nauczaniu, ponieważ metoda projektów przygotowuje do praktycznego działania. Nauczanie w ten sposób ma ponad 90-procentową skuteczność i jest zgodne z powiedzeniem Konfucjusza: „Usłyszałem - zapomniałem, zobaczyłem - zapamiętałem, zrobiłem - zrozumiałem”. Dotychczasowe nauczanie często nakierowane było na teorię. Uczeń 
najpierw poznawał zagadnienie czysto teoretycznie, a dopiero potem wykonywał praktyczne ćwiczenie. W treściach nauczania w większości punktów uczeń ma wyjaśniać pojęcia, zjawiska czy przykłady ekonomiczne. Są to treści nastawione na wiedzę teoretyczną. Natomiast w punkcie dotyczącym wyboru szkoły i zawodu podane są konkretne umiejętności, które uczeń ma opanować na tym etapie, tzn.:

- umiejętność planowania swojej dalszej edukacji,

- umiejętność wyszukiwania informacji o zatrudnieniu na lokalnym, regionalnym i krajowym rynku pracy,

- umiejętność napisania życiorysu i listu motywacyjnego,

- umiejętność znalezienia przyczyn bezrobocia w swojej miejscowości, regionie i w Polsce. W modyfikacjach celów kształcenia przedsiębiorczości na etapie gimnazjum w dalszym kroku modyfikacji można przenieść zalecenia do obowiązku. Obowiązuje realizacja 20\% treści w formie projektu. Dzięki temu uczeń nabędzie umiejętności planowania, współpracy, debatowania, krytycznego myślenia, publicznej prezentacji. W podstawie programowej nauczania wiedzy o społeczeństwie dla gimnazjum znajdują się zagadnienia dotyczące przedsiębiorstwa i działalności gospodarczej. Uczeń spotyka się z tą wiedzą jeszcze raz na następnym etapie kształcenia - w szkole ponadgimnazjalnej. Na tym etapie rozwoju młodego człowieka dla ucznia ważne są zajęcia warsztatowe, w szczególności z zakresu komunikacji interpersonalnej, poświęcone:

- komunikacji werbalnej i niewerbalnej,

- sposobom rozwiązywania konfliktów,

- ocenie własnych predyspozycji zawodowych (w polskim systemie szkolnictwa wybór szkoły średniej i klasy o określonym profilu, ze względu na przedmioty zdawane na maturze i związane z tym możliwości studiowania, ma decydujący wpływ na wykonywany w przyszłości zawód),

- pracy zespołowej - znaczącą modyfikacją byłoby wprowadzenie do podstawy programowej obowiązku prowadzenia tych zajęć w formie warsztatu, a nie wykładu.

Kształcenie postawy przedsiębiorczości wymaga:

- rozciągania się poza życie zawodowe,

- ciagłej poprawy,

- organizowania konkursów przedsiębiorczości dla młodzieży w formie gier, symulacji itp.

- wprowadzania do kształcenia dzieci przez nauczycieli przedszkolnych i nauczania początkowego programu nauczania przedsiębiorczości poprzez gry i zabawy.

Trudno jest znaleźć projekty dotyczące przedsiębiorczości w przedszkolach i szkołach podstawowych. Kilka lat temu pracowałam w szkole podstawowej, w której sklepik szkolny był prowadzony przez uczniów. Sprzedawali oni artykuły spożywcze i inne podczas przerw. Opiekunem grupy był nauczyciel matematyki. Za zarobione pieniądze uczniowie wyjeżdżali na wycieczki. Ta inicjatywa zasługiwała na nagrodę. Podobny projekt, nazwany Cap Ten, realizowany w Brukseli zachęca do przedsiębiorczości już w szkole podstawowej. Dzieci w wieku 10-12 lat wykorzystują materiały, które rozwijają ich kreatywność, niezależność, otwartość, poczucie odpowiedzialności oraz umiejętności komunikacji. Uczestnicy projektu sami określają wyzwanie, którego chcą się podjąć, i wykorzystują swoje osobiste talenty, używając specjalnie dostosowanego do tej grupy wiekowej zestawu narzędzi do zarządzania projektami. Głównym celem inicjatywy jest zmiana mentalności w państwach członkowskich UE, w których najmniejszy odsetek obywateli chce otworzyć własną firmę. Projekt dostarcza pełną metodologię, a nie tylko ,podręcznik z instrukcjami”. Projekt Cap Ten otrzymał Nagrodę za Inwestowanie w Kapitał Ludzki za innowacyjność stosowanych metod oraz z uwagi na znaczenie wczesnej edukacji zachęcającej do przedsiębiorczości. 
(www/ec.europa.eu/enterprise/policies/sme/best-practices/european-enterpriseawards/competition-2007/winners/index_pl.htm).

Przedsiębiorczość zaczyna się w przedszkolu od kształtowania w dzieciach chęci poszukiwania innowacyjności oraz wiary we własne siły. W Stanach Zjednoczonych promuje się postawy przedsiębiorcze od przedszkola, np. dzieci przygotowują z rodzicami prezentacje o swoim domowym zwierzątku i przedstawiają ją przed grupą dzieci w przedszkolu. W trakcie tworzenia prezentacji dziecko kupuje np. z rodzicami żywność, orientując się dzięki temu, jaki jest koszt utrzymania zwierzęcia. W ten praktyczny sposób ,programuje się” dziecko do przedsiębiorczego myślenia i dochodzenia do wiedzy przez działanie. Na poziomie szkoły podstawowej nauczanie przedsiębiorczego projektowania i działania polega na rozwoju kreatywności, własnej inicjatywy i samodzielności. W tej fazie wypracowuje się aktywne formy nauczania poprzez wprowadzanie odpowiedniego programu dla nauczycieli nauczania początkowego oraz przygotowanie skryptów i warsztatów z gotowymi propozycjami gier i zabaw. Ważnymi elementami w tej dziedzinie są:

- nawiązywanie w podręcznikach dla dzieci szkół podstawowych do praktycznych zagadnień ekonomicznych znanych im z codziennego życia,

- wychowywanie dzieci na krytycznie myślących konsumentów poprzez wspólne działania nauczycieli i rodziców.

Narodowy Bank Polski przygotował internetowe komiksy dla dzieci i młodzieży. Z inicjatywy studentów SGGW z Warszawy powstał komiks pt. Oskar i Bajer zakładaja własna firme. Studenci prowadzą lekcje przedsiębiorczości dla klas 5 i 6 szkół podstawowych. Z kolei młodzieży w wieku 15-20 lat Fundacja Przedsiębiorczości proponuje różne projekty, tak aby uczniowie ,tworzyli swoją zawodową egzystencję nie tylko jako pracobiorcy, ale również jako pracodawcy".

Obecnie w naszym kraju w biedzie żyje co trzeci Polak. Osoby te posiadają często słabo wykształcone cechy przedsiębiorczości, co jest jedną z przyczyn ubóstwa. Wynikiem tego stanu jest brak możliwości decydowania o swoim losie. Co zrobić, aby te osoby wyrwać ze stanu marazmu i „nicnierobienia”? Trzeba u nich zaszczepić kulturę przedsiębiorczości i wiary we własne siły.

Edukacja w przedsiębiorczości to nieustanne kształtowanie kreatywności i innowacyjności. Gospodarka i szkoła muszą współpracować ze sobą, ponieważ światem rządzi biznes. Tam, gdzie jest dobra edukacja, tam jest i bogactwo. Przedsiębiorczość prowadzi uczniów do sukcesu, dlatego są potrzebni nauczyciele potrafiący kształtować odpowiednie cechy u dzieci. Dzięki takim nauczycielom uczniowie nabywają umiejętności projektowania swojej przyszłości oraz zaangażowania w działania. W tym celu dla nauczycieli nauczania początkowego powinny być przeprowadzane różne szkolenia przygotowujące ich do kształtowania przedsiębiorczych postaw u dzieci. Dotychczasowe hasło ,gospodarki opartej na wiedzy” powinno być zamienione na „gospodarkę opartą na umiejętnościach”. Przy powszechnym dostępie do wiedzy liczyć się będzie to, aby uczeń chciał i umiał korzystać z wiedzy. Kształtowanie umiejętności będzie kluczowym aspektem rozwoju gospodarki. Drugim ważnym elementem jest ciagły rozwój nauczania przedsiębiorczości w szkołach - od przedszkola aż po uniwersytety, a także ustawiczne samokształcenie się społeczeństwa.

Nauczanie przedsiębiorczości w warunkach integracji europejskiej jest bardzo ważną częścią kształtowania gospodarczej przyszłości. Na stronach internetowych Komisji Europejskiej możemy znaleźć specjalne publikacje dotyczące przedsiębiorczości, np. przewodnik nauczyciela z przykładami dobrych praktyk promowania postaw przedsiębiorczych. W nowym okresie programowania kluczowym zadaniem będzie oparcie gospodarki i społeczeństwa na umiejętnościach i postawach. 
Na skutek powszechnej dostępności do wiedzy większe znaczenie będzie mieć sprawność korzystania z zasobów teoretycznych. Posiadanie biegłości i postawy do wykorzystania nauki w społeczeństwie będzie czynnikiem postępu w warunkach gospodarek konkurencyjnych. Kształtowanie przedsiębiorczej postawy u dzieci jest najlepszym rozwiązaniem dla przyszłości i dobrej jakości życia społeczeństwa, ponieważ ,gospodarka to nie wszystko, ale bez gospodarki wszystko jest niczym".

\section{Literatura}

1. Bartel H.P., Ohne Wirtschaft ist alles nichts, Berliner Republik, „Das Debattenmagazin”, 1/2003.

2. Europäische Kommission, 2004, Hilfe zum Aufbau einer unternehmerischen Kultur; dokument elektroniczny, tryb dostępu: www.ifte.at/documentos/entrepreneurial_culture_de.pdf, (8 września 2009).

3. Sielatycki M., Kompetencje nauczyciela w Unii Europejskiej; dokument elektroniczny, tryb dostępu: www.trendy.codn.edu.pl (stan na dzień 2 września 2009).

4. Żochowska M., Michałowski M., 2008, Oskar i Bajer zakładaja własna firmę, NBP.

\section{Teaching Entrepreneurship in the Context of the European Integration}

This paper is intended to prove the need to teach entrepreneurial society from kindergardens and to prepare all necessary measures to boost creative activity and entrepreneurial skills in children and teenagers. Every third Pole lives in poverty currently in Poland. These people have poor intelligent entrepreneurial features and this is one of the reason of their poverty. What can we do with those people from the depressed and 'nothing to do' culture? We can inoculate them with entrepreneurial culture and they have to believe in themselves. Entrepreneurial culture means developing creativity and innovation constantly. Economy and school have to cooperate together because the world is business. Where there is a good education, there is a wealth of economy. The entrepreneurial spirit leads students to success in their life. Therefore, teachers should prepare to teach them and shape of entrepreneurial attitudes in students. This programming period distributed password 'economy knowledge-based' and in the new programming should be altered 'economy skills-based'. While access to knowledge is easy, student's willingness and skills play a vital role. Therefore, boosting skills is a key aspect of economy development. 